\title{
Capabilities and knowledge transfer: evidence from a university research center in the health area in Mexico
}

\author{
Capacidades y transferencia de conocimiento: evidencia de un centro \\ de investigación universitario en el área de salud en México
}

\author{
Arturo Torres Vargas ${ }^{1 *}$, Javier Jasso Villazul \\ ${ }^{1}$ Universidad Autónoma Metropolitana, México \\ ${ }^{2}$ Universidad Nacional Autónoma de México, México
}

Received November 26, 2017; accepted November 19, 2018

Available online November 28, 2018

\begin{abstract}
One of the questions in the current debate about innovation processes is how to transfer knowledge and technology from universities to the productive sector. The objective of this work is to analyze the role of the scientific and inventive capabilities generated in the universities, as a requirement to promote effective processes of knowledge and technology transfer to the productive sector. With this, we seeks to contribute to the understanding of how an effective linkage between universities and the companies can be fostered to create and develop innovative products through the transfer of technology. We analyse the experience of the Institute of Biomedical Research of the National Autonomous University of Mexico, one of the most important universities in Latin America (IIBm-UNAM). This university research center (URC) stands out in the Mexican context for its relevant generation of scientific and inventive capabilities. It is concluded that for the knowledge created in the universities to materialize in new products and / or processes marketable by the productive sector, it is crucial that there are complementary capabilities between the university and the companies. In this process two driving forces are identified. The first "sci-

\footnotetext{
*Corresponding author.

E-mail address: atvargas@ hotmail.com (A. Torres Vargas)

Peer Review under the responsibility of Universidad Nacional Autónoma de México.
} 
ence push" requires from universities to generate scientific and inventive capabilities that enable new scientific and technological developments, as well as the capabilities to manage and transfer that knowledge. The second "demand pull", requires that companies generate capabilities to identify, use and assimilate the scientific and technological university developments. Both processes enable the transfer of knowledge and technology from universities to the productive sector.

JEL Codes: I23, I15, O31, D83, B52.

Keywords: Capabilities, knowledge transfer, technology transfer, universities-firm 1 inkages, u niversity r esearch centers, health, Mexico.

\section{Resumen}

Una de las preguntas en el debate actual sobre los procesos de innovación es cómo transferir el conocimiento y la tecnología de las universidades al sector productivo. El objetivo de este trabajo es analizar el papel de las capacidades científicas e inventivas generadas en las universidades, como requisito para promover procesos efectivos de transferencia de conocimiento y tecnología al sector productivo. Con esto, buscamos contribuir a la comprensión de cómo se puede fomentar un vínculo efectivo entre las universidades y las empresas para crear y desarrollar productos innovadores a través de la transferencia de tecnología. Se analiza la experiencia del Instituto de Investigaciones Biomédicas perteneciente a la Universidad Nacional Autónoma de México (IIBm-UNAM), una de las universidades más importantes en América Latina. Este instituto en el contexto mexicano destaca por su relevante generación de capacidades científicas e inventivas en el área de la salud. Se concluye que para que el conocimiento creado en las universidades se materialice en nuevos productos y/o procesos comercializables por el sector productivo, es crucial que existan capacidades complementarias entre la universidad y la empresa. En este proceso se identifican dos fuerzas impulsoras. La primera "empuje de la ciencia" proveniente de las universidades, que deben generar capacidades científicas e inventivas que posibiliten nuevos desarrollos científicos y tecnológicos, así como las capacidades para gestionar y transferir el conocimiento. La segunda "tirón de la demanda", requiere que las empresas generen capacidades para identificar, utilizar y asimilar dichos desarrollos científicos y tecnológicos universitarios. Ambos procesos posibilitan la transferencia de conocimientos y de tecnología de las universidades al sector productivo.

Códigos JEL: I23, I15, O31, D83, B52.

Palabras clave: Capacidades, transferencia de conocimiento, transferencia de tecnología, vínculos entre universidades y empresas, centros de investigación universitaria, salud, México.

\section{Introduction}

In Mexico the development of scientific and technological capabilities in the area of health has been carried out slowly, despite that it has had a great tradition especially in the twentieth century, with the beginning of medical specialties (Mas, 2012).

Mexico's investment in health research is only 2.3 percent of the total spent on science and technology, accounting for 0.01 percent of GDP and 0.45 percent of total health spending, which contrasts sharply with the spending in industrialized countries, which is generally above 1.5 percent of public spending on health (SSa, 2007). Mexico's low spending on research and its slow development among other factors has prevented a major gap between the health needs of the population and the reality of research and technological development. 
In this context, universities and public URC are called to play a crucial role not only as producers of human resources and knowledge-generating activities through their teaching and research functions. They are also called upon to contribute significantly to economic expansion and social development (Arocena \& Sutz, 2005, Maietta, 2015). However, little is known about the processes by which scientific and technological knowledge is transferred from universities and public research centers to the productive and social sectors (González-Pernia et al, 2013; Chang et al, 2016; Ramos \& Fernández-Esquinas, 2012; Calcagnini \& Favaretto, 2015).

The potential of URC to contribute to economic and social development (the university's third mission) lies in its ability and effort to generate scientific and technological capabilities, as well as to disseminate their use. Capability building is a key element for the transfer process to take place.

Based on the IIBm-UNAM, this work identifies the capabilities generated by this URC, and explains to what extent these have formed a basis for promoting technological developments that are oriented and used to solve health problems. As emphasized in the report of the Global Forum for Health Research (1999), strengthening health research capacities is necessary to contribute to the correction of the 10/90 gap, which refers to the fact that only $10 \%$ of the funds for health research in the world are aimed at researching the health problems that affect $90 \%$ of the world's population

It investigates the patterns of inventive activities and scientific production conducted by IIBm-UNAM ${ }^{1}$ and illustrates the knowledge transfer process with marketable results of this URC with companies in the pharmaceutical sector. Bibliometric and patent indicators are used to account for the construction of scientific and inventive capabilities. In order to investigate the transfer process, a qualitative design based on interviews with personnel of the related agents is used: the URC and the pharmaceutical company. Interviews were conducted bewteen the end of 2016- beginning of 2017. ${ }^{2}$

Complementary sources such as annual reports, internal reports and web pages are used. The selection of IIBm-UNAM is derived from previous studies, in which it stands out as a relevant PRO to illustrate the knowledge generation and transfer process. The IIBm-UNAM has a long history (founded in 1941) and an important performance in the generation of scientific capabilities and the number of patents created, within the Mexican context. It is located in a relevant sector due to its economic and social impact (health) and has had some experiences in the transfer of knowledge with marketable potential to Mexican pharmaceutical firms.

This paper is structured into five sections. Following this first section that introduces the subject and describes the methodology, the second is aimed to provide an analytical framework by reviewing the topic of knowledge and technology transfer from the universities perspective. Sections three and four present the empirical results of the research, concerning the potential of the IIBm-UNAM in terms of scientific and inventive capabilities, which form its basis to feed the innovation processes of companies and other agents, and the analysis of two examples

\footnotetext{
${ }^{1}$ The acronym UNAM refers to the Universidad Nacional Autonoma de Mexico (National Autonomous University of Mexico). We also use IIBm to refer to the Instituto de Investigaciones Biomédicas (Institute of Biomedical Research).

$\underline{2}$ We acknowledge the personnel of the Institute of Biomedical Research of the UNAM for the facilities and support for carrying out this work, especially the personnel of the Department of Neurosciences PhD. Maria Sitges Berrondo; Q.F.B. María Araceli Guarneros López (Academic Technician) and Biol. Luz María Chiu Velázquez (Academic Technician). Other interviewees requested confidentiality.
} 
of technology transfer carried out by this research institute. The fifth section contains some conclusions.

\section{Analitical framework}

In a broad sense, the transfer of knowledge refers to a process by which science and technology diffuse into human activities.

The transfer of knowledge forms one of the principal axis of the third mission of the university since this allows institutions of higher education and URC to contribute in the solution of needs with economic and social impact. The evolutionary approach to the economy, associates innovation with schemes that characterize it as the result of a process that takes place in an economic, political and social environment in which a diversity of actors constituting the National Innovation System are involved and linked (Freeman 1995; Lundval et al, 2002). The interaction of URC with industry and in general with the productive sector is one of the crucial elements of the innovation process. The scientific knowledge generated by research centers is increasingly determined by the interaction between agents who use and reinterpret such knowledge. This is a result of the growing importance and development of research work in the contemporary university and also the effect of the progressive importance of knowledge as a determinant of international competitiveness and the development of economies.

According to recent studies on university-firm linkages, the process of transferring knowledge between universities and industry occurs through multiple channels such as human resources training, publications, staff mobility, informal contacts, consulting, R\&D projects (joint and contract, patents and spin-offs (Dutrénit et al., 2010; Torres et al., 2011). From the industry perspective, studies suggest that the most important channels are publications, intellectual property rights, human resources, joint R\&D projects, and networking (Cohen et al, 2002, Dutrénit et al, 2010). The process of transferring knowledge from universities to public and private users can be assimilated to a value chain, from the research carried out in URC to their transformation into new or improved products or services which companies will bring to market (Testar, 2012). Within this scheme, technology transfer is conceived as one of the multiple ways through which the transference of knowledge can take place. In the field of economic activities, we can characterise technology transfer as the process of incorporation into a productive unit, of the knowledge developed outside it. The licensing agreements have been one of the most important channels for the transfer of technology from the university to private firms in developed countries. More often inventions emerging from universities and URC labs need extensive development before an actual product or service is ready to be marketed and used by the people. During the last decades, several entities have been established whose purpose is to increase the likelihood that the knowledge and technological results of the universities will be successfully commercialized, such as business incubators and accelerators, science parks, technology transfer offices, interface units, and different forms of formal or informal interaction between universities and companies (Sargent \& Mathews, 2014; Puerta \& Jasso, 2018). Technology transfer is a complex process, which can follow different trajectories, with universities, companies and economic development entities participating in different phases. In Figure 1, we propose a scheme to show the mechanisms that can be identified in the process of knowledge transfer, from the perspective of both, universities and companies. 


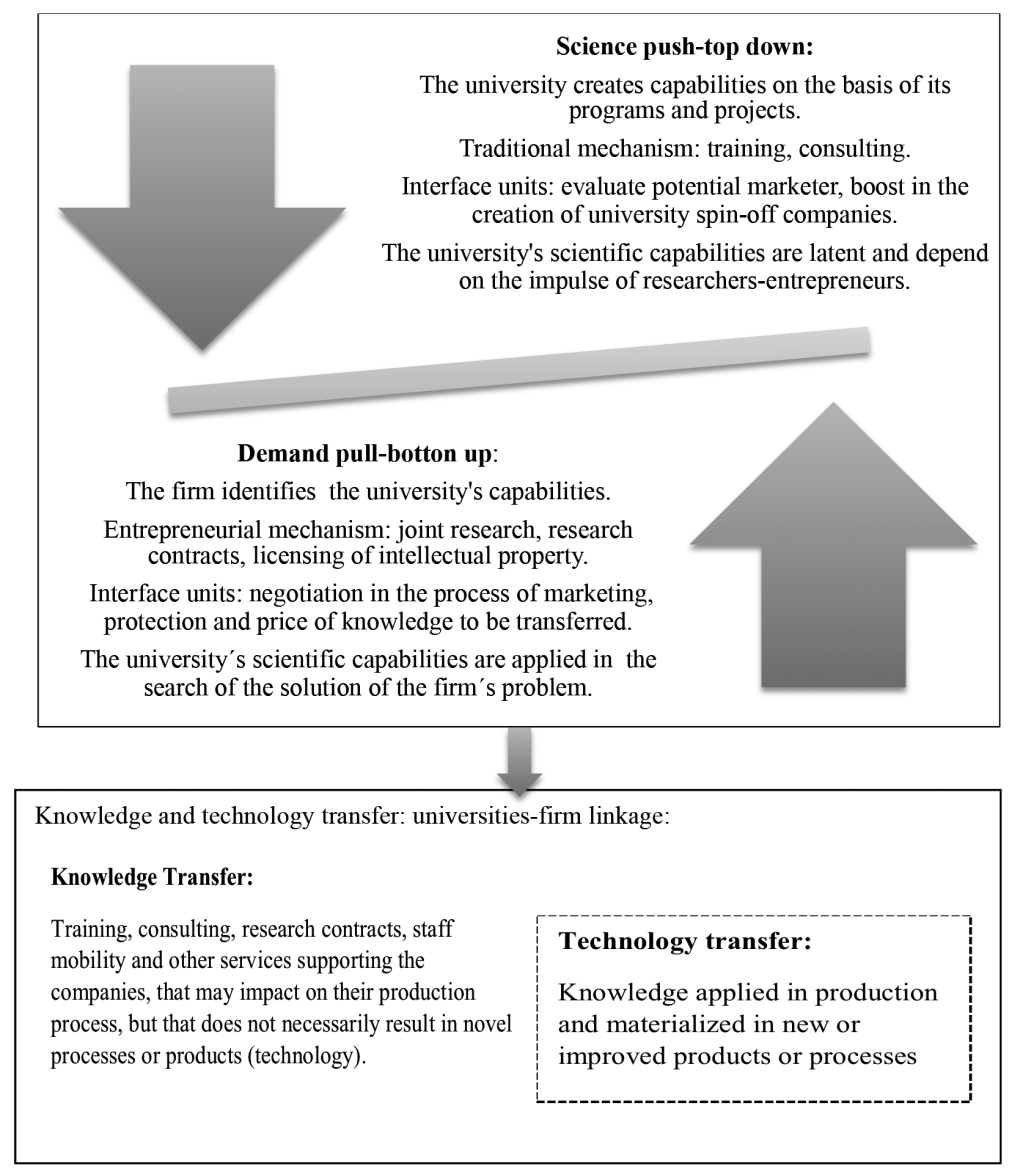

Figure 1. University-firm linkages: transfer of knowledge and capabilities.

Source: own elaboration.

According to the scheme, there are two main mechanisms in the knowledge transfer process. The first is one in which science is a driving force of transference from the side of the universities "science push". In the second "market pull" the demand pulls the process (Testar, 2012). In the first case, knowledge is transmitted via consulting, training staff, technical assistance activities. In the second, the main modalities of transfer are contract research, research via joint projects, and the sale or licensing of ownership of research results generated in universities. Channels of interrelation between universities and firms can be either bottom-up or top-down.

The first type is more spontaneous and corresponds to the case where actors who need knowledge to solve technical problems or develop innovations meet (on their own initiative) with actors that can provide knowledge. The second (top down) is characterized by the fact that the linkage is concretized through formal and legal institutional mechanisms that propose initiatives to strengthen relations between the university and the company (ECLAC, 2011). 
Technology transfer is a process through which knowledge and skills are disseminated, materializing in products, processes or techniques feasible to be used, and in innovations that meet some economic and/or social need.

The building of scientific and technological capabilities involves the construction and strengthening of problem-solving research capabilities, while this process needs to promote the construction of basic general capabilities in different fields (Clark et al, 2002).

In the present research, the scientific capabilities encompass those learnings associated with the generation of new knowledge created by following the scientific method to identify and to deal with the problems, in this case related to health. It is the capability building of URC that constitutes the real basis for interaction (Simmie \& Strambach, 2006). These capabilities feed or drive innovation processes, coupled with efficient schemes for knowledge transfer and intellectual capital formation. We must remember that scientific research produces new knowledge, but only a fraction of this is expressed, frequently after a long journey, in new products and processes, or in the improvement of existing ones (Kreiman \& Maunsell, 2011).

In order for academic knowledge to be transferred, the university requires the creation of capabilities for the sale or licensing of any form of industrial property (patents, utility models, brands, among others); the transmission of specialized know-how in the form of plans, manuals, formulas; the transmission of knowledge for the acquisition, installation and use of machinery and equipment; and/or materials for the training of personnel, and provision of specialized services (Calcagnini \& Favaretto, 2015; Testar, 2012).

An important facilitator in the process of commercialization of scientific knowledge is the linking and technology transfer offices that assist universities in the commercialization of scientific research, evaluating the commercial viability of new technologies, management and protection of intellectual property, promoting the association to carry out research with the business sector, and supporting the creation of university spin-offs (González-Pernia et al, 2013).

\section{Scientific and technological capabilities in health research: evidence from UNAM-Mexico}

\section{Capabilities in the health sector in Mexico}

The areas of health research involve two main aspects (cognitive and practical) that together attribute a social function to health research: i) multiply scientific knowledge and ii) define mechanisms for its application in society. The first aspect reflects its utility or return to society, this can occur through its dissemination through different means (publications, courses, seminars, workshops, conferences, etc.) which in turn allow the generation of new knowledge or training of human resources; the other aspect corresponds to the practical application of its results in the prevention, improvement and solution of health problems.

In general, most national research (in all fields and areas) is carried out in institutions of higher education (62\%) followed by institutions in the public sector $(36 \%)$ and lastly in private institutions (0.7\%). In the health area in Mexico, in 2012 companies and URC had obtained 182 patents, $46 \%$ of URC attached to universities, $19 \%$ to URC of health and $35 \%$ of companies. Inventions predominate in drugs $(82 \%)$ and the remaining $18 \%$ are diagnoses and treatments and medical devices (Jasso, 2015). Among the drugs, vaccines predominate. This specialty has a knowledge and scientific base linked to the type of patents that have been obtained. Thus, devices and artefacts are associated with mechanical, electrical and electronic knowledge, 
drugs with the chemical-biological area and the care area that is, with the provision of services, diagnostics and treatment.

Scientific and inventive capabilities at the Institute of Biomedical Research of the UNAM

The Institute of Biomedical Research-UNAM (IIBm-UNAM), is one of the main research centres from the National Autonomous University, one of the leading and oldest Universities in Latin América. The IIBm develops research and supports the training of human resources to contribute to the advancement of biomedical knowledge and help solve the country's biomedical problems. It's core participation in strategic university projects such as the human genome and vulnerable diseases positions it in a privileged place in research within the UNAM. In this section, based on indicators of publications and patents, we identify the level of scientific capabilities (second mission) to identify innovation capabilities and especially transfer cases to the productive sector. The transfer is illustrated on the basis of two patents transferred to the productive sector.

The IIBm-UNAM has promoted the development of science in Mexico and its mission is the study of biological phenomena at the molecular, cellular, organic and population level, as well as the projection of their knowledge and technologies to the understanding and solution of human diseases. The institute appears in 1941, in the Old School of Medicine. In 1954 it acquired the category of Institute of Medical and Biological Studies, and in 1969 it is constituted as Institute of Biomedical Investigations.

The IIBm-UNAM has two headquarters in Ciudad Universitaria, Mexico City and several peripheral units located in the National Institutes of Health and Universities of the States. Researchers at the Institute are affiliated to four research departments that focus on human health: Molecular Biology and Biotechnology (33\% of researchers), Genomic Medicine and Environmental Toxicology with $32 \%$ and the remaining $35 \%$ of the Departments of Cell Biology and Immunology (UNAM, 2015).

The research lines are structured in multidisciplinary programs that have the orientation of solving health problems. By 2017 the institute had 87 researchers and 83 academic technicians. $90 \%$ of them belong to the National System of Researchers (IIBm-UNAM, 2017), whose work is also reflected in the area of basic research and in the production of original articles published in scientific journals which are internationally recognized. The IIBm-UNAM has directly or indirectly promoted the creation of other research centers and institutions in Mexico, such as the Brain Research Unit of the National Institute of Neurology and Neurosurgery, the Research Unit in Reproductive Biology of the IMSS and the Division of Neurosciences of the Mexican Institute of Psychiatry.

In Mexico, the UNAM is the institution with the most patents applied for in 2017 (WIPO, 2017). Health research at this university is carried out mainly in 5 centers and research institutes; within these the IIBm-UNAM is the third in importance, according to the indicators of scientific and inventive capabilities (Figure 2). 


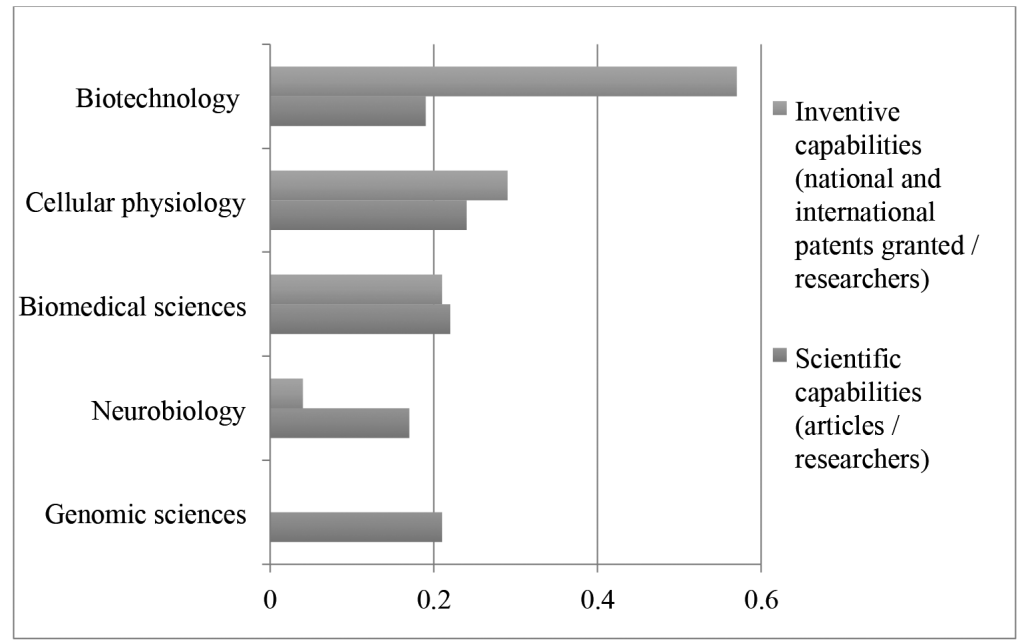

Figure 2. UNAM. Research institutes capabilities in the area of health, 2000-2014. Source: own elaboration, with data from UNAM (2015). La Ciencia en la UNAM 2015. A través del Subsistema de la Investigación Científica, UNAM.

From 2000 to 2017 the scientific output of the IIBm-UNAM was of 1,896 indexed articles in Scopus. Since 2005, its scientific capabilities have importantly grown. Publications increased from 24 in 2004 to 130 in 2015 (Figure 3). Since 2012, more than 100 articles have been published annually, bringing the annual average to 83.94 articles.

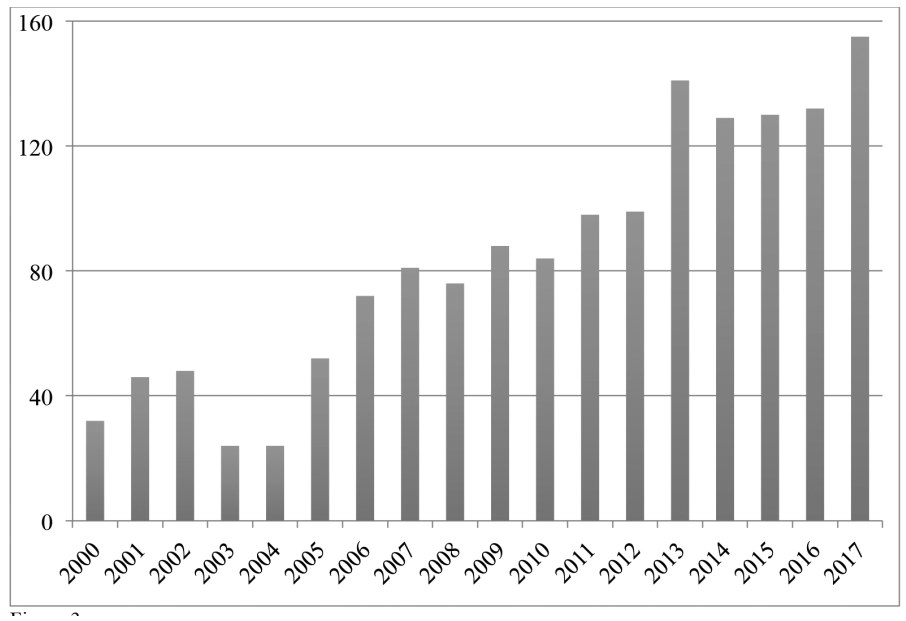

Figure 3. UNAM, Institute of Biomedical Research (IIBm-UNAM).

Scientific capabilities (number of publications), 2000-2017

Source: own elaboration, with data from UNAM (2015) La Ciencia en la UNAM 2015. A través del Subsistema de la Investigación Científica, UNAM; IIBm- UNAM. Instituto de Investigaciones Biomédicas, annual reports 2015, 2016 and 2017 and Scopus (2018). 
IIBm-UNAM has generated significant inventive skills; it is estimated that it is the institute with the highest number of patents granted, of those dedicated to health issues within the UNAM. During the analyzed period, 31 patents obtained by the IIBm-UNAM were identified; on average 1.72 patents were obtained per year (Figure 4 ).

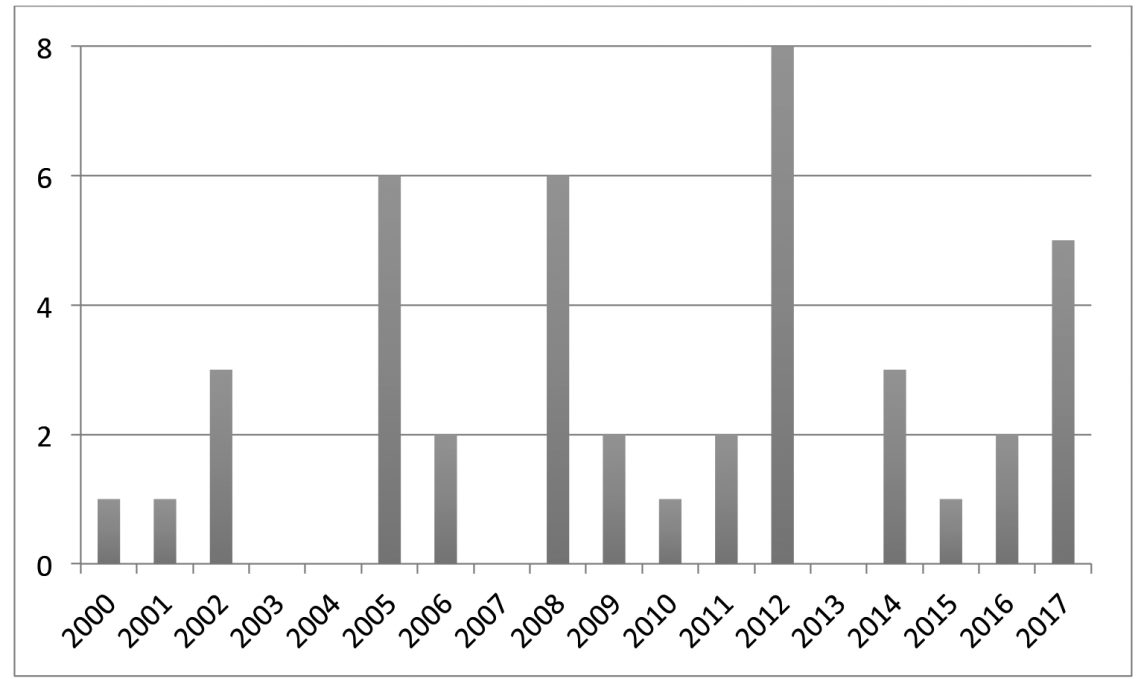

Figure 4. UNAM, Institute of Biomedical Research (IIBm-UNAM). Inventive capabilities (number of patents granted), 2000-2017

Source: own elaboration, with data from UNAM (2015) La Ciencia en la UNAM 2015. A través del Subsistema de la Investigación Científica, UNAM; IIBm- UNAM. Instituto de Investigaciones Biomédicas, annual reports 2015, 2016 and 2017 and Scopus (2018)

At least one-third of the researchers from the IIBm-UNAM with more indexed publications (Scopus, 2018) do so with other researchers belonging to different URC, such as the National Institutes of Health, IMSS and Cinvestav, and Mexican universities such as those from Veracruz and Tlaxcala states. In a little more than $10 \%$ of cases, IIBm researchers have coauthored with researchers from the US, and to a lesser extent with researchers from Europe and South America (Scopus, 2018). The research areas in which the IIBm has focused are medicine (26\%), biochemistry, genetics and molecular biology (25\%), and immunology and microbiology (15\%). These three areas concentrate $66 \%$ of the total of the remaining 22 areas that make up their scientific capabilities (Figure 5). 


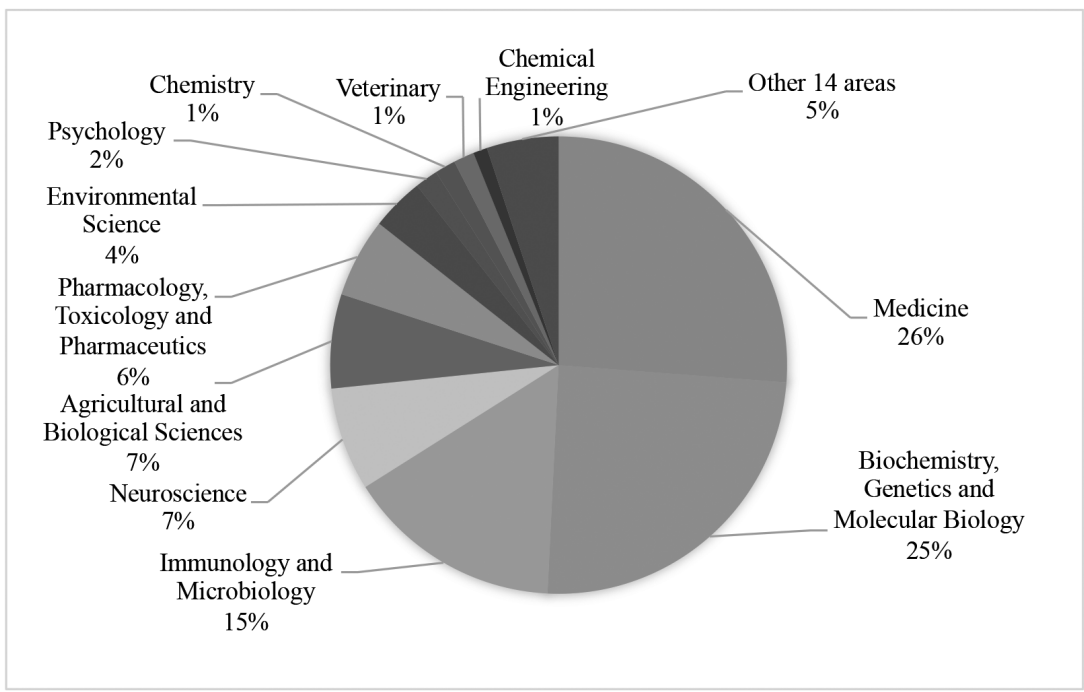

Figure 5. UNAM, Institute of Biomedical Research (IIBm-UNAM). Specialization of the scientific capabilities, 2017 (number of publications).

Source: own elaboration, with data from Scopus (2018).

Regarding to patent ownership, the IIBm-UNAM has jointly filed patent applications with Cinvestav, the Autonomous University of Puebla, the National Institute of Neurology and Neurosurgery and the Autonomous University of the State of Morelos.

This performance evidences that the capabilities of the IIBm-UNAM have been built by its own efforts and in collaboration with other URC and universities, and even with the productive sector, which coincides with the Mexican public policy of boosting the scientific and technological capacity promoted by the National Council for Science and Technology (CONACYT), and the UNAM itself from the institutional programs such as the National System of Researchers (NSR) and the internal stimulus in the UNAM. These capabilities also translate into the transfer of technology to the productive sector, as detailed below.

\section{Knowledge and technology transfer from Institute of Biomedical Research of the UNAM}

As already mentioned, the transfer of knowledge and technology is the central axis of the so-called third mission of the university; transferring knowledge does not necessarily imply transferring technology, since technology is knowledge embodied in products, while knowledge can be transferred through other channels such as teaching and training, consulting and joint projects.

\section{Transfer dynamics: channels and mechanisms}

The interaction of the IIBm-UNAM with the companies is relevant, especially considering the little linkage that generally occurs in Mexico, but it is scarce if we consider the networks that 
the leading pharmaceutical companies carry out with other research centers at an international level. In the IIBm-UNAM, linking was initially via traditional services such as the use of the institute's infrastructure and laboratory tests, and as the relationship matured, the mechanisms were extended to joint research projects.

The IIBm-UNAM has supported companies in the development of solutions for the care and improvement of health, promoting the application of scientific and inventive university capabilities that respond to specific health problems of the Mexican population. The transfer of patents and the provision of services have been promoted in recent years. The contracts were initiated through informal relationships. Among the pharmaceutical laboratories that have established links with the IIBm-UNAM, there are foreign and mexican companies such as Bristol-Myers, Boeringher Ingelheim, Johnson \& Johnson, Merck, Landsteiner Laboratories, Alvartis Pharm, Qsar Analytics, Esteripharma, Altecsa, Carnot Laboratories, Biofabrica Siglo XXI, Alandra Medical SAPI, Sophia Laboratories, Liomont, and Neolpharma Pharmaceutical Group (NPG).

\section{Capabilities for technology transfer}

In this proposal, it is argued that the process of technology transfer requires that agents (URC and companies) have complementary capabilities. On one hand, URC must have the capabilities to generate transferable knowledge, to manage and commercialize it. On the company side, skills are needed to identify and assimilate the knowledge required to boost their learning processes and technological innovation. Schematically, this is summarized in two forces that make transfer possible for innovation: a) science push, which involves creating transferable knowledge and the process to get it to the agent who will take it to the market and b) the demand of the company, that is to say, the absorption (by the companies), to assimilate the knowledge and the skills to put it into practice.

A minority of URC have the capabilitities to participate in patenting activities. On the other hand, there is also a small number of companies that have sufficient capabilities to absorb the innovations derived from R\&D activities of the URC. In light of these considerations, it is not strange that the transfer of knowledge, via licensing and technology transfer contracts, is not very significant.

In IIBm-UNAM, the role of the Linking Unit of this research center has been important for transfer processes. This unit supports and advises the staff of the Institute in specific agreements or collaborations, and in legal aspects and management of intellectual property with the productive and social sector.

We identified two patents, one already transferred and another in the process of being transferred to the national pharmaceutical industry. These were two projects carried out with the company Psicofarma, related to the launching of medicines within the Mexican market. Transfers were made as part of the agreement established by the IIBm-UNAM with the company, so that this one had priority in the exploitation of the technological development. The approaching between the company and the IIBM has used informal mechanisms, but it has also been an instrumental function of the interface units created by the IIBM-UNAM.

\section{The transfer for the cancer treatment}

One of the transference cases is the use of hydralazine and procanaimide in the treatment of cancer as reactivators of expression in tumor suppressor genes. The patent has been granted to 
the IIBm-UNAM. The second relates to the use of transcriptome modifying agents plus cancer chemotherapy or radiation therapy and is applied for patent in Belize, Brazil, Canada, China, Colombia, Costa Rica, Ecuador, the United States, Mexico, Nicaragua, New Zealand and Russia. It has a technology licensing agreement (PCT / MX2005/000106 application number) to the company Psicofarma.

According to Ostrovsky (Fundacion, UNAM, 2012), "it is a question of finding markers that allow to diagnose this disease especially in specific cases, because this condition increasingly appears at younger ages, and in those circumstances, it can be more aggressive and resistant to treatments. So far, one of the markers is whether the tumors are estrogen-sensitive or not. If this is the case, in addition to extirpating them, estrogen production is prevented either by drugs or by ovariectomy to avoid the production of this hormone.

Although there are other markers, these used are negative to some patients in whom the cancer appears at an early age, so we have focused on these negative tumors and together with researchers from the National Cancer Institute we look for other biomarkers that allow us to detect them early and investigate effective treatments to care for patients who are in this condition.

Transkrip is a drug that can be used in cervical cancer therapy. This drug was developed by a team of IIBm researchers, led by Ph. D. Alfonso Dueñas, in the Peripheral Unit of the National Cancer Institute, and with the participation of the Mexican company NPG. Obtaining the product, from the conception of the idea, until its commercialization, lasted about 8 years, which is a relatively short time. This is an example of drug repositioning, which is a strategy based on the use of existing drugs.

\section{The transfer for the treatment of epilepsy}

Although several drugs for the control of epilepsy exist on the market, no effective drug was known in the effective treatment of epilepsy without having side effects. After a long process of investigation in the IIBm-UNAM, and as a result of the alliance with Psicofarma, a drug with these characteristics is expected to reach the market.

Experimental research on the effects of vipocetine on brain nerve terminals began at the IIBm-UNAM approximately 16 years ago. These were carried out by $\mathrm{Ph}$. D Sitges researcher of the department of cell biology and physiology, together with Dr. Nekrassov from the National Institute of Rehabilitation.

The technological development consists of an anticonvulsive drug to control the epilepsy in patients who do not respond to the conventional treatment. In this case, it is also a therapeutic repositioning. The drug does not cause adverse side effects and is in the process of national and international patent (2012), in partnership with Psicofarma Laboratory, S.A. of C.V., which will commercialize it with the name of Stabilliza. The contact between the IIBm-UNAM and the company was originated from the request of Psicofarma to perform tests of molecules in the Department of Cell Biology and Physiology.

The project consists of the use of vinpocetine to prevent the hearing-related complications that accompany epilepsy and its treatment. This treatment has been obtained in several countries as a patent and is in process in others. It has a technology licensing agreement. The researcher worked with staff of the Department of Neurology of the Children's Hospital of Mexico, where the clinical trials of the drug were carried out in human patients. 


\section{Demand as a driving force for the application of university-generated capabilities}

The company Psicofarma is part of NPG, a pharmaceutical group that is 100\% of Mexican property, whose origin can be found more than three decades ago. Within this group the processes of research, development, pharmacovigilance, manufacture and commercialization of medicines of high specialty and of general use are integrated. With a portfolio of approximately 200 products, this group is one of the 5 largest providers of the public health sector and is among the 10 largest Mexican laboratories in the private sector.

The company Psicofarma emerged in 1974 as a Mexican laboratory dedicated to the production of drugs for the care of patients with psychiatric and neurological conditions. Recently adding to their production of anticoagulants, antidepressants, psychostimulants and antipsychotics, new products related to the care of chronic diseases, and a biogenetic division dedicated to high specialty medicines. Alpharma, is part of the group dedicated to producing medicines for diabetes, obesity, hypertension, rheumatism, among others. It is also the local representative of several laboratories in Europe. Neolpharma emerges as a holding company, resulting from the merger of Psicofarma with the Neolpharma plant (1995), the absorption of the Schering-Plow plant (2011) and the purchase of another one from Pfizer in Puerto Rico (2013) that adds to its organic growth, highlighting its plant in Mexico City, in 2009, dedicated to the manufacture of oncological and biotechnological products.

As an important part of its strategy NPG has strengthened its relationship with educational institutions and research centers to form multidisciplinary groups, with the purpose of promoting innovation processes. It has established research partnerships with the National Cancer Institute, the National Institute of Neurology and Neurosurgery, the Mexican Institute of Psychiatry, the Institute of Biomedical Research, the Children's Hospital, the National Rehabilitation Institute, the Metropolitan Autonomous University, the National Autonomous University of Mexico FES Cuautitlán (Faculty of Higher Education) and the Cinvestav (Center for Research and Advanced Studies).

NPG also maintains links with the General Hospital, Hospital Juárez, Mexican Institute of Social Security (IMSS), and ISSSTE (Social Security Institute at the Service of State Workers) for the development of clinical protocols. Through the NPG Center for Pharmacovigilance, Research and Early Detection of Clinical Alterations of Mexico (CIDAT-NPG), activities of pharmacovigilance, investigation and early detection of clinical alterations are carried out, establishing close contact with the patients; with the purpose of identifying any adverse reactions to the drugs, for which they carry out clinical analysis, cabinet studies and monitoring of clinical studies. NPG invests $10 \%$ of the group's total sales in research and development activities. The alliances with the academy have resulted in the application of four patents, with coverage in Mexico, Canada, the United States, the European Union, Asia and Latin America.

The company is making strong lobbying to quickly enter the United States, with innovative and generic drugs. The value of the US generic market is estimated at 100 billion dollars annually, while in Latin America it is 70 billion dollars. At the level of the pharmaceutical industry in Mexico, Neolpharma participates with about $1.7 \%$ of the market.

\section{Therapeutic repositioning: an impulse-to-transfer strategy}

The scientific advance from the university was through the therapeutic repositioning, that is of the study of known drugs. The repositioning of drugs is a strategy that consists of using existing drugs in new therapies. According to some studies, traditional research on new drugs 
can take between ten and fifteen years, and more than one billion dollars per molecule. Many of these processes are left along the way, either because molecules may not be proven effective or some present toxicity and safety problems in tests with cell cultures, animal models or clinical trials in humans. The difficulties that exist in pharmaceutical $\mathrm{R}+\mathrm{D}+\mathrm{i}$ have led the scientific community to propose new ways to address classic problems, one of which is repositioning. This is the strategy followed by the IIBm-UNAM and Neolpharma in the two experience analyzed.

In 2010, the cancer treatment drug was approved by the Federal Commission for Protection against Health Hazards (COFEPRIS) for marketing in advanced uterine cervical cancer. In 2011 it was authorized to treat myelodysplastic syndrome and is expected to be approved shortly for cutaneous lymphoma.

The Biomedical Cancer Research Unit (UIBC) played a crucial role in the development of this process. The UIBC was created in 2000, as the result of a joint effort of IIBm-UNAM and the National Cancer Institute (INCan). The UIBC is located in the research building of the INCan and its objective is to strengthen existing research in the INCan, as well as to initiate new lines of research to foster the generation of high level knowledge in oncology.

The UIBC's location within the INCan, the reference center and governing body of cancer in Mexico, promotes its researchers to come into closer contact with the public health problems of neoplastic diseases, providing opportunities for both basic and clinical researchers, and the possibility of carrying out multidisciplinary research projects focused in the oncological area.

Research areas at the UIBC include the study of the etiology, biology, epidemiology, treatment and diagnosis of the most common cancers in Mexico, such as the cervix, breast, ovary, lung, prostate, lymphomas and leukemias. Currently, the UIBC has 11 laboratories and a vivarium to keep experimental animals. Each laboratory is lead by at least one researcher, all members of the SNI. Subsequently, relations were established with the Institute of Physics of the UNAM creating a laboratory of medical physics. In addition, the INCan hired a researcher whose line of research is cancer gene therapy; the preparation of this laboratory has been financed by Psicofarma, S.A. of C.V.

The development of Transkrip illustrates the advances and the impact that can be derived from the connection between the URC and the companies in the health sector, as well as the interface mechanisms. The patent is owned by the UNAM, which has licensed it, with a contract duration at the expiration of the patent, i.e. it will be extended for 20 years. UNAM receives royalties, that is a percentage of sales. This is regulated by the Revenue Regulations of the university; the agreement was processed and negotiated with the company and the legal area of the UNAM.

The IIBm-UNAM shows that it is necessary to have own clinical development models that involve the active participation of academic centers, and of health institutes, including those of high specialty. Otherwise basic research will not have the necessary impact on national pharmaceutical development, nor will it have any impact that benefits society.

\section{Conclusions}

The experience of the public research university analyzed provides elements to illustrate that the potential of the university to contribute to economic and social development lies in its ability and effort to generate capabilities, as well as to disseminate their use. 
In the IIBm-UNAM the articulation with the hospitals has been crucial. Highlighting the creation and operation of Peripheral Units, located in different national health institutes, with general hospitals and medical centers.

The process of transferring knowledge from universities to public and private users can be assimilated to a value chain, from the research carried out in the URC, to their transformation into new or improved products or services that companies will bring to the market.

Two cases of knowledge transfer with practical applications of IIBm-UNAM to the company Psicofarma, part of a $100 \%$ Mexican ownership pharmaceutical group (Neolpharma), were identified. In both, the process begins on the basis of the scientific and inventive capabilities of IIBm, following a scheme in which the generation of science is the initial factor that pushes the process (science push). However, this can trigger a market pull process, once established the long-term link between companies and universities, promoting research via joint projects.

The transfer presupposes the strengthening of the university not only as an organization that generates knowledge, but also as manager of itself. An important part for the transfer to occur is the existence of a greater number of companies that in their strategy favor innovation. In the case analyzed, we find that the Neolpharma Pharmaceutical Group has strengthened its relationship with educational institutions and research centers, in order to promote innovation processes.

The challenge of university-business linkage seems to lie in how to reinforce the transfer value chain in a double-flow scheme. This is on the one hand increasing the volume of research results that have the potential to be incorporated in the transfer process (role of the universities), and on the other hand to generate the conditions of an increased demand pull, that is to say a growing set of significant companies and other private and public bodies that are able to identify the innovative potential of knowledge generated in universities and to demand it.

In the chain of the innovative process, it is important to generate knowledge and the existence of interface units, but so is the environment in which universities and companies are developed. The existence (or not), of a critical mass of researchers, of institutional conditions that foster linkage, or of a context that drives companies to innovate are necessary.

\section{Acknowledgment}

We acknowledge the support of CONACYT through project entitled "Transferencia de conocimiento orientada hacia problemas nacionales de salud: el caso de la diabetes", founded by the "Fondo de Ciencia Básica" (CB2015-258387) and of UNAM through the project "Innovación y capacidades en el sector salud en México", founded by the "Programa de Apoyo a Proyectos de Investigación e Innovación" (IN309416). We thank the personnel of the Institute of Biomedical Research (UNAM) for their support to carry out this work.

\section{References}

Arocena, R. \& Sutz, J., (2005). Latin American universities: from an original revolution to an uncertain transition. Higher Education, 50 (4), 573-592. https://doi.org/10.1007/s10734-004-6367-8

Calcagnini, G., \& Favaretto, I., (2015). Models of university technology transfer: analyses and policies. Journal of Technology Transfer, 41( 4), 655-660. https://doi.org/10.1007/s10961-015-9427-6

CEPAL. (2011). Espacios Iberoamericanos: vínculos entre universidades y empresas para el desarrollo tecnológico. Santiago de Chile.

Chang, X., Chen, Q. \& Fong, P. (2016). Scientific disclosure and commercialization mode selection for university technology transfer. Science and Public Policy, 43, 85-101. https://doi.org/10.1093/scipol/scv011 
Clark, W., Corell, R., Glaser, G., Hassan, M., Calestous J. Mabogunje A, Rosswall Th., \& Sarukan, J. (2002). Science and Technology for Sustainable Development: Consensus Report of the México City Synthesis. Workshop, Initiative on Science and Technology for Sustainability (http://sustainabilityscience.org/ists/synthesis02.htm), 20-23 May, 2002, Cambridge, MA.

Cohen, W., Nelson, R. \& Walsh, J., (2002). Links and impacts: the influence of public research on industrial R\&D. Management Science, 48(1),1-23. https://doi.org/10.1287/mnsc.48.1.1.14273

Fundación UNAM, (2012). Publicado el 9 enero, In Fundación UNAM http://www.fundacionunam.org.mx/de_la_ unam/unam-recibe-premios-canifarma-2012/.

Dutrénit, G., De Fuentes C., \& Torres, A., (2010). Channels of interaction between public research organisations and industry and benefits for both agents: evidence from Mexico. Science and Public Policy, 37 (7), 513-526. https:// doi.org/10.3152/030234210x512025

ECLAC (2011). Espacios Iberoamericanos: vínculos entre universidades y empresas para el desarrollo tecnológico, Santiago de Chile.

Freeman, C. (1995). The National System of Innovation in Historical Perspective. Cambridge Journal of Economics (19), 5-24 https://doi.org/10.1093/oxfordjournals.cje.a035309

Gonzalez-Pernia, J.L., Kuechle, G., \& Peña-Legazkue, I., (2013). An assessment of the determinants of university technology transfer. Economic Development Quarterly, 27 (1), 6-17. https://doi.org/10.1177/0891242412471847

IIBm-UNAM, Instituto de Investigaciones Biomédicas (varios años). Informe de Actividades. Instituto de Investigaciones Biomédicas, UNAM, DF. http://www.biomedicas.unam.mx/html

Jasso, J., (2015). Innovación y salud: agentes, redes y desarrollo. In Ranfla A., Rivera M. \& Caballero, R. (coordinadores) Desarrollo económico y cambio tecnológico. Teoría, marco global e implicaciones para México. México, Juan Pablos, UNAM, UABC, pp. 175-204.

Kreiman, G. \& Maunsell, J. (2011). Nine criteria for a measure of scientific output. Frontiers in Computational Neuroscience, 5 (48), 1-6. doi: 10.3389/fncom.2011.00048

Lundval, B., Johnson, B., Andersen, E., \& Dalum, B. (2002). National systems of production, innovation, and competence building. Research Policy 31(2), 213-231. https://doi.org/10.3389/fncom.2011.00048

Maietta, O., (2015). Determinants of university-firm R\&D collaboration and its impact on innovation: A perspective from a low-tech industry. Research Policy 44 (7), 1341-1359. https://doi.org/10.1016/j.respol.2015.03.006

Mas, J., (2012). Aspectos sociales de la vinculación en salud, entre academia y sociedad. México, UNAM-RED PUISAL.

Puerta, L. \& Jasso, J. (2018). University-industry linkage and technology transfer management, A quantitative study of an entrepreneurial university. Journal of Management Development 37 (7), 573-585. https://doi.org/10.1108/ JMD-06-2017-0203

Ramos-Vielba, I. \& Fernández-Esquinas, M., (2012). Beneath the tip of the iceberg: exploring the multiple forms of university-industry linkages. Higher Education, 64 (2), 237-265. https://doi.org/10.1007/s10734-011-9491-2

Sargent, J., \& Matthews, L. (2014). Latin American Universities and Technology Commercialization. Latin American Businees Review, 15 (2), 167-190. https://doi.org/10.1080/10978526.2014.905163

Scopus (2018). Bse de datos Scopus. http://bibliotecas.unam.mx/index.php/conoce-recursos-electronicos/390-scopus. Consultado en octubre de 2018.

Secretaría de Salud (2007). Programa Nacional de Salud 2007-2012: Por un México sano: construyendo alianzas para una mejor salud, Secretaría de Salud, México, D.F.

Simmie, J., \& Strambach, S., (2006). The contribution of KIBS to innovation in cities: an evolutionary and institutional perspective. Journal of Knowledge Management, 10 (5), 26-40. https://doi.org/10.1108/13673270610691152

Testar, X., (2012). La trasferencia de tecnología y conocimiento universidad-empresa en España: estado actual, retos y oportunidades. Colección Documentos CYD, Fundación CYD, No. 17. Barcelona, España.

Torres, A., Dutrénit, G., Sampedro J.L, \& Becerra, N. (2011). Whar are the factors driving university-inustry linkages in latecomer firms: evidence from México, Science and Public Policy, 38(1), 31-42 https://doi.org/10.3152/0302 $34211 \times 12924093660390$

UNAM (2015). La Ciencia en la UNAM 2015. A través del Subsistema de la Investigación Científica, UNAM.

WIPO, World Intellectual Property Office (2017). The Global Innovation Index 2017. In [http://www.wipo.int/edocs/ pubdocs/en/wipo_gii_2015.pdf]. Consultado en febrero de 2018. 